\title{
Mistisisme dalam Pemilin Kematian
}

\author{
Ardi Wina Saputra \\ Universitas Katolik Widya Mandala Madiun \\ c.ardi_7@yahoo.com
}

\begin{abstract}
Abstrak
Mistisisme sangat melekat dengan masyarakat Indonesia. Mistisisme sering kali dijadikan sebagai ornamen dalam kesusastraan Indonesia. Mulai dari kesusastraan lama, sastra lisan, hingga sastra tulis. Di era 2000-an ini mistisisme yang notabene merupakan kekayaan inetelektual bangsa, sangat jarang digunakan karena dianggap kuno. Namun penulis muda Dwi Ratih Rahmadhany menggunakan mistisisme dalam kumpulan cerpennya berjudul Pemilin Kematian. Penelitian ini menilai kajian mistisisme dalam cerpen Pemilin Kematian karya Dwi Ratih Rahmadhany. Metode penelitian ini adalah deskriptif kualitatif. Temuan dalam penelitian ini adalah cerpen-cerpen yang memiliki muatan mistisisme dalam Kumpulan Cerpen Pemilin Kematian.
\end{abstract}

Kata Kunci: cerpen; kumpulan; mistisisme

\begin{abstract}
Mysticism is very attached to Indonesian society. Mysticism is often used as an ornament in Indonesian literature. Starting from old literature, oral literature, to written literature. In this era of the 2000s mysticism which incidentally was the nation's intellectual wealth, was very rarely used because it was considered ancient. But the young writer Dwi Ratih Rahmadhany uses mysticism in his collection of short stories entitled Pemilin Kematian. This study assesses the study of mysticism in Pemilin Kematian short stories by Dwi Ratih Rahmadhany. The method of this research is qualitative descriptive. The findings in this study are short stories that have a mystical content in the Collection of Short Discipline Short stories.
\end{abstract}

Keywords: short story; collection; mysticism

\section{PENDAHULUAN}

Karya sastra di era 2000 an ini berkembang dengan amat pesat. Raudal Tanjung Banua, salah seorang sastrawan dalam sebuah diskusi di kafe Pustaka mengatakan bahwa para generasi muda sedang gencar-gencarnya dalam meneroka sastra Indonesia. Meneroka berarti membuka lahan baru, mengembangkan, membuka tempat baru khazanah sastra Indonesia. Ada dua persyaratan yang diperlukan yaitu perlunya konsistensi atau keajegan, serta perlunya kedalaman dalam bersastra. Apabila kedua hal ini terpenuhi, maka kebaruan sastra atau penerokaan sastra dapat diamini. 
Salah satu sastrawan muda yang berusaha untuk meneroka sastra ini adalah Dwi Ratih Rahmadhany. Melalui cerpen-cerpennya dalam kumpulan cerpen berjudul pemilin kematian (2015), dia mulai menawarkan sajian sajian mistisisme khususnya dalam hal feminis.

Prof. Dr. Djoko Saryono, dalam prolognya berpendapat bahwa tokoh-tokoh yang terdapat pada cerpen berjudul Pemilin Kematian ini memiliki kesadaran naif, bukan kesadaran semi transitif, sehingga tampak terobsesi dengan peristiwa kematian yang supranatural. Lebih lanjut, Dosen jurusan sastra ini mengatakan bahwa kesadaran mists lebih dominan dibandingkan dengan kesadaran ontologis yang fungsional, sehingga banyak menjadikan kematian yang supranatural tercermin dalam cerpen ini.

Kesadaran dalam Pemilin Kematian ini menarik untuk diteliti. Dwi Ratih Rahmadhany merupakan penulis muda dari Madura yang memberikan warna dalam cerpen-cerpen di belantara sastra Indonesia, khususnya dalam hal prosa fiksi. Salah satu keunggulanya terletak pada kekuatan teknik bercerita dengan menyajikan hal-hal mistis yang seringkali dikaitkan dengan nilai-nilai tradisi.

Penelitian sebelumnya dilakukan oleh Saeed Zarabidaseh (2011) berjudul Mendefinisikan Mistisisme. Penelitian ini menghasilkan simpulan berupa definisi mistisisme dari berbagai sumber dan dimensi literatur yang kemudian ditarik menjadi definisi yang komprehensif. Penelitian selanjutnya dilakukan oleh Tjahjono Widijanto (2018) bertajuk Jagad Alus Mistis Jawa dalam Cerpen-Cerpen Danarto dan
Fantasi Magis Ternate dalam Novel Cala Ibi Karya Nukila Amal. Penelitian ini menghasilkan temuan berupa nilai-nilai Jawa dalam cerpen-cerpen yang ditulis oleh Danarto dan temuan mengenai Fantasi Magis yang ditulis dalam Novel Cala Ibi.

Berdasarkan dua penelitian tersebut, peneliti ingin melengkapi kajian literatur mengenai penelitian mistisisme dengan meneliti cerpen-cerpen penulis muda Dwi Ratih Rahmadhany.

Menurut Prof Djoko saryono terdapat tiga hal yang perlu diperhatikan dalam meneroka sastra Indonesia. Pertama, adalah siapa yang memandang. Sudut pandang sastra diambil oleh masyarakat umum secara general atau para ahli dan akademisi sastra yang terspesialisasi. Kedua adalah dengan menggunakan instrumen apa memandangnya. Unsur intrinsik, ekstrinsik, interdisipliner ilmu atau transdisipliner ilmu. Ketiga, sasaran yang dijelajah atau objek sastranya yang seperti apa? Sastra kanon ataukah sastra serius.

Prespektif saat ini menjadi penting karena pengetahuan itu sekarang semakin lama semakin netral . Kenetralan pengetahuan ini diakibatkan oleh banjurnya ilmu yang masuk atau obesitas informasi. Setelah reformasi, sebenarnya ilmu ilmu termasuk semua bidang ilmu ini sudah mulai pudar. Semua diberi kebebasan sehingga menjadi bebas sebebasbebasnya arus informasi yang masuk. Ditambah lagi dengan Teknologi Informasi dan Komunikasi (TIK) yang semakin merajalela. Ini membuat para pengarang dan stakeholder berlomba lomba memasukkan karyanya dan menyebarkan sendiri melalui media internet. Dampak utamanya adalah pudarnya batas-batas sastra dan bukan sastra. 
Sejak reformasi sebenarnya kita sedang menyaksikan kematian sastra itu sendiri. Semua orang ingin menyebut dirinya sebagai penyair akibatnya tidak ada syair karena semua terasa sama saja. Terasa hambar. Semua ingin menjadi sastrawan tanpa ada Makomnya, tanpa ada batasannya tanpa ada pengkritiknya. Bukan hanya sastra sebenarnya, hampir semua juga mengalami hal serupa. Gayatri sebagai dengan bukunya The Death of Dicipline dengan tegas menguak mampusnya ilmu-ilmu. Matinya ilmu-ilmu, arus kehidupan seperti Tong Setan yang selalu berputar. Gravitasi yang berupa batasan, norma, dan etika serta aturan yang lama sudah tidak terlalu dihiraukan lagi.

Saat ini yang terjadi adalah tiga kelompok karya sastra yaitu (1) fiksional, (2) rasional, dan (3) sains. Sastra gologan pertama merupakan sastra yang secara sosial tidak dbagus terlebih menurut pandangan kapitalis. Sastra jenis ini masih setia pada makomnya, imajinatif, simbolik, dan kontemplatif. Contoh karya jenis ini adalah Cantik Itu Luka, Telegraf, dan novel karya Ayu Utami. Hubu juga masih berada di level satu. Sastra yang seperti ini telah mengalami proses yang panjang. Penulis yang lahir tidak instan, mereka menimba ilmu sastra dan memperdalam kajian tentang sastra dengan serius sehingga mampu menciptakan karya yang berkualitas sekaligus bernas.

Sastra kategori berikutnya adalah sastra yang erat kaitannya dengan realita. Terdapat dua jenis karya ini yaitu based on true story dan traveling literature. Based on true story berangkat dari realita penulis. Selanjutnya adalah traveling literature. Baru baru ini muncul traveling fiction, yaitu sastra perjalanan. Kejelasan dan batasan kualitas sekali lagi masih harus dipertanyakan dalam jenis karya yang satu ini. Karya yang berbasis pada realitas juga ada yang mengambil sisi realitas historis seperti Gajah Mada dan karya lainnya. Auto etnografi juga mulai diminati. Mensastrakan pengalaman seorang tokoh seperti Sepatu Untuk Dahlan.

Kebebasan internet juga menciptakan hadirnya Sastra Waktu Luang. Sekarang dengan mudahnya oang mengupload karyanya dan membagikannya dalam jejaring sosial. Parahnya lagi di jejaring sosial terlaris saat ini yaitu facebook, diberikan ikon tombl suka atau like, bukan dislike. Inilah yang membuat pembaca tinggal mengeklik sajaa apabila rekan tersebut mengupload karyanya. Sebagai wujud simpati bukan apresiasi.

\section{METODE}

Metode penelitian yang digunakan dalam penelitian ini adalah kualitatif. Landasan filosofis yang digunakan dalam penelitian kualitatif adalah landasan filsafat postpositivisme atau paradigma interpretive (Sugiyono, 2013:17). Postpositivisme merupakan aliran teori kritik yang bersifat modernis dan bertentangan dengan unsur tradisional. Creswell (1994:4) bahkan menyatakan bahwa terdapat aliran postmodernisme yang dipengaruhi oleh Baudrillad, Lyotard, dan Derida dalam penelitian kualitatif. Menurut Burbach (dalam Chandradewi 2014:2) postmodernisme merupakan pergeseran beberapa aspek ilmu sosial. Pergeseran ini disebabkan karena sifat modernisme yang masih bersifat homogen dengan standardisasi yang telah ditentukan. Postmodernisme seperti halnya 
postpositivistik hadir untuk mendobrak serta mengkritisi paradigma ini. Callinicos (2008:15) mengatakan bahwa postmodernisme memacu terjadinya revolusi.

Berdasarkan pengertian dan landasan filosofis tersebut, maka penelitian ini menggunakan metode kualitatif. Sumber data dalam penelitian ini adalah kata, kalimat, hingga wacana dalam kumcer Pemilin Kematian karya Dwi Ratih Rahmadhany. Penelitian dilakukan dengan tiga tahap yaitu (1) membaca Kumcer Pemilin Kematian, (2) mengolah data dalam kumcer yang berkaitan dengan mistisisme, dan (3) menyajikan data tersebut dalam bentuk artikel penelitian.

\section{HASIL DAN PEMBAHASAN}

Judul Pemilin Kematian diambil karena hampir semua kisah diakhiri atau berdekatan dengan peristiwa mati itu sendiri. Pengemasannya yang memperhatikan aspek kearifan lokal serta tak ketinggalan dengan segala sesuatu yang bersifat kekinian atau kontemporer, merupakan nilai tambah dalam cerpen ini.

Buku ini dibuka dengan judul cerpen Pemilin Kematian. Pada judul tersebut dikisahkan sesosok emak yang kehadirannya seolah seperti seorang dukun. Geertz (1989:116) mengatakan bahwa di Jawa, unsur terpenting dukun adalah dukun itu sendiri, lepas dari dia lelaki atau perempuan yang terpenting adalah karismanya. Sosok emak dalam cerpen pemilin kematian ini digambarkan sebagai seorang dukun, karena dia tahu sebab musabab kematian seseorang dan mampu memprediksi kapan kematian tersebut terjadi dan menghampiri tokoh-tokoh lain yang kehadirannya secara tersirat. Seperti halnya dalam penggalan cerpen berikut:

Perempuan itu tak pernah berharap suapa pun mati setiap hari. Ia bahkan tak ingin menggantungkan hidupnya pada tubuhtubuh kaku dan ruh merea yang telah pergi menjauh. Tetapi perempuan itu telah menjelma bagai maut yang telah menghampiri urat nadi. Apabila kau putus asa dan ia datang padamu dengan sebilah senym serta sentuhan lembut di pundakmu, maka kau akan tahu bahwa perempuan itu akan datang pada hari kematianmu.

Sosok dukun yang ada dalam diri emak sejatinya bukan dukun yang bersifat tukang sihir atau komersil, melainkan dukun yang mampu memprediksi dan merupakan bakat alami. Mak adalah seorang dukun murni bukan tukang sihir. Cremers dan Santo (1997:10) menerangkan bahwa ada tiga prasyarat seseorang dikatakan sebagai tukang sihir, yaitu:

1. Memiliki kepercayaan pada teknik yang diterapkan

2. Kepercayaan konsumen atau klien terhadap dukun, dan

3. Kepercayaan konsumen atau klien pada dukun yang berfungsi semacam gratisasi

Ketiga aspek dukun sebagai tukang tidak nampak dalam diri Mak. Itu terbukti bahwa tokoh Emak memilin kematian sebenarnya bukan karena suruhan dari konsumen, melainkan dari sebuah insting yang muncul secara alami. Di akhir cerita, ceren ditutup dengan sangat mengejutkan yaitu dengan kematian Emak itu sendiri yang tidak diketahui oleh semua orang. Kematian emak adalah dengan cara gantinng diri dan menukar kematiannya dengan orang lain. Emak ingin terhindar dari api neraka sehingga dia 
melakukan hal tersebut untuk mengakhiri hidupnya. Apa yang dialami oleh Emak ini mengutip pendapat Peterson (2004:19) bahwa pada dasarnya manusia sering merasa dirinya itu sinting. Itulah yang dialami oleh Emak, dia merasa kurang waras semenjak suaminya meninggal. Akibatnya adalah banyak cerminan rasa takut yang teraktualisasi menjadi satu dalam sebuah wujud tindakan bunuh diri.

Cerpen berikut yang tak kalah mistisnya adalah cerpen berjudul Biaju Direngkuh Rengas sungai Kahayan. Cerpen ini merupakan cerpen dengan kearifan lokal yang tinggi. Dikisahkan di sebuah desa di Kalimantan yang memiliki pohon renggas. Namun sayang pohon renggas itu malah menciptakan petaka. Mitos bagi siapa saja yang mendekatinya akan terkena kutukan, seolah menjadi mitos yang sejak lahir diturunkan. Mitos menurut Keesing (1981:106) adalah sesuatu yang berupa asal mula terjadinya dunia misteri, cerita tentang alam gaib, dan sejenisnya yang seolah-olah mirip dengan dunia nyata.

Pohon renggas yang dikisahkan dalam cerpen tersebut sangat sakti sehingga membuat yang mendekatinya terkena tulah. Itulah sebab para tokoh digiring untuk tidak mengetahui apa yang sebenarnya terjadi dalam hutan yang berisi pohon renggas itu. Seolh-olah pohon renggas telah dianggap sebagai suatu hal yang tabu. Menuut Freud (2002:31), makna tabu sebenarnya bercabang dua arah. Pada suatu sisi, tabu berarti bahwa kudus, suci, dan di sisi lain berarti berbahaya serta kotor. Berikut adalah kutipan cerpennya:
"Tapi kata orang, Tapang sering cari renggas di dekat tempat pangkalima? Tak boleh, Pang. Nanti bisa seperti Pak Sawun kulitnya," tukas Gema sambil mengipasngipas.

"Kata Siapa? Itu karena dia tak hati-hati. Lagi pula aku kan tak merusak, hanya iseng jalan-jalan cari ikan dan kayu di sekitar sana. Kadng sama monyet, tak masalah," timpalnya.

"Kan sudah kubilang, kata orang nanti Tapang bisa kena tulah kalau tak perisi," timpal Gema.

Tiga penggal percakapan cerpen tersebut menunjukkan perdebatan yang sangat hebat antara Gema dan Tapang. Tulah dan ktukan renggas diyakini sangat kuat sehingga mendekat pun tak ada yang boleh. Namun dalam cerpen dikisahkan bahwa Tapang adalah seorang yang pemberani dan keras kepala, bahkan dia tahu bahwa renggas meskipun beracun namun memiliki kualitas yang bagus.

Ratih, sebagai pengarang dalam cerpen ini berusaha menciptakan interpretasi pada benak pembaca mengenai penyalahgunaan mitos. Kita tahu di Kalimantan sering terjadi penebangan hutan dan pembakaran. Salah satu jenis pohon yang ditebang adalah pohon renggas yang dikisahkan memiliki kualitas bagus namun beracun. Keberadaan renggas dianggap tabu agar masyarakat pedlaman tidak tahu menahu tentang khasiat dan kebermanfaatan pohon itu. Itulah sebabnya maka dalam cerpen, mendekat pohon renggas berarti menantang maut.

Hal tersebut dibuktikan dengan keberanian Biaju, ibu Tapang yang tidak terima melihat puteranya mati di pohon renggas. Bertekad baja dan mengesampingkan mitos, maka pergilah Biaju menuju tempat 
pohon renggas itu. Anehnya Biaju juga menghilang, cerita ditutup dengan Gema yang merupakan adik dari Tapang sekaligus anak sulung Biaju bersama dengan orang-orang mencari keberadaan Biaju, namun sayang Biaju tak ditemukan.

Orang-orang berteriak memanggil nama Biaju dan bertekad menyebar tak jauh dari lokasi ditemukannya sarung dan senter Biaju. Mereka terus berteriakmengikuti jejak darah atau apapun yang mencurigakan. Di hadapan mereka, sebagian pohon tumbang dan ditebang.

Penggalan cerpen di akhir cerita tersbeut merupakan pembuktian bahwa sejatinya, penciptaan mitos pohon renggas jelas jelas untuk tujuan tertentu. Sayangnya itulah yang terajdi sat ini, masyarakat pedalaman yang masih primitf tcenderung termakan oleh mitos ini, padahal mitos diciptakan untuk sebuah tujuan tertentu oleh kaum kapitalis, dalam hal ini para penebang hutan untuk menjaga keajegan hutan tersebut agar tak dikuasai penduduk sekitar.

Cerpen berikutnya yang masih dapat dikaji melalui kajian mistisisme yaitu cerpen berjudul Malam Merah Ibu. Pada cerpen ini, ibu dikontraskan menjadi dua hal. Di sisi lain, ibu diibaratkan sebagai seorang hero yang melindungi anaknya, namun justru itu yang membuatnya menjadi iblis. Pengiblisan ini tampak secara tak langsung dalam cerpen.

Malam Merah Ibu mengisahkan tentang percakapan seorang Ibu dan anak gadisnya bernama Rana yang sedang belajar membatik. Rana, anak gadisnya yang mungil itu menanyakan perihal keberadaan ayahnya. Di sini, sosok ayah adalah sosok yang pemarah dan menyeramkan. Ayah Rana merupakann sosok pengangguran yang pemarah dan seperti orang stress. Dia suka melampiaskan emosinya pada istri dan anaknya. Di sisi lain, Nafa sang istri hanya bisa sabar dan membatik. Dari hasil membatik inilah keluarga ini masih bisa bertahan.

Di rumah, Nafa mencoba mengingatkan suaminyaberkali-kali namuntak digubris. Anton benar-benar menjelma serigala jahat. Rana pun sering dimarahinya bahkan perihal kecil tentang kegiatan di sekolahnya. Nafa sangat terpukul, ia hanya bisa menjauhkan Rana dari sengat amarah suaminya dan mengatakan bahwa Anton hanya lelah. Setiap hari, hatinya beribu kali babak belur oleh makian Anton, bahkan tak jarang Anton memukulinya jika Nafa melawan perkataanya. Setiap hari, kalau tak punya lembar rupiah untuk berjudi.

Penyiksaan secara lahiriah dan batiniah dialami oleh Nafa. Tak tahan dengan hal ini, Nafa pun mulai bergejolak. Roh jahatnya mulai muncul karena sering dijahati oeh suaminya. Khan (2002:77) menegaskan bahwa Roh merupakan representasi jiwa dan pikiran manusia. Saat roh jiwa dan pikiran tersebut dikontaminasi oleh hal-hal yang jahat maka roh pun ikut menjadi jahat bahkan bisa jadi akan lebih jahat dari manusia, atau pada tataran iblis. Itulah yang terjadi pada Nafa, dia menjelma menjadi sosok iblis yang jahat.

Dengan segenap amarah yang menyulut, Anton memakinya. Namun kali ini Nafa tak mau mengalah. Ia balas meneriaki suaminya dengan air mata berderai-derai di pipinya. Dipukulinya Anton, dan direbutnya gunting di dalam genggaman suaminya. Batinnya berteriak melolonglolong bahwa dia sudah cukup bersabar menghadapi kelakuan bejat suaminya. Ditancapkannya gunting itu ke perut Anton 
berkali-kali, bertubi-tubi. Tanpa ampun. Asu!.

Seolah kerasukan setan, Nafa belum puas dengan hal itu. Ia mengumpulkan darah suaminya yang tak henti mengalir. Ia menyeka darah segar itu dengan kain batik yang telah robek tak keruan dan diperssnya ke atas wajan sebagai ganti malam-malam yang tumpah. Diseretnya sekuat tenaga tubuh Anton menuju gentong besar tempat ia mencuci batiknya sat oroses pelorotan. Biar begitu. Biar tenang hatinya yang seperti disayat sembilu.

Penggalan dua paragraf di akhir tersebut membuktikan bahwa pengiblisan terjadi pada jiwa pada pemikiran, hingga pada ruh Nafa sehingga Nafa tega berbuat demikian. Perbuatan itu bukanlah cerminan perbuatan manusia, melainkan perbuatan setan yang tak kenal ampun. Dehumanisasi dilakukan oleh Nafa pada suaminya, sebab perlakuan suaminya yang juga bentuk dehumanisasi telah terakumulasi pada batin Nafa.

Cerpen terakhir yang layak untuk dikaji adalah Janda Sungai Gayam. Puncak atau klimaks proses kreatif penulis seolah tersaji dalam cerpen Janda Sungai Gayam. Menggunakan nama tokoh yang sama dengan nama penulis, yaitu Ratih. Penulis seolah ingin menunjukkan jati dirinya dan tolok ukur kemampuan bersastranya. Lepas dari cerpen Janda Sungai Gayam yang mendapatkan berbagai penghargaan, cerpen ini memang terbilang sebagai cerpen yang matang. Kematangan penulis benar-benar teruji dalam penokohan hingga alur ceritanya.

Kajian mistisisme dalam artikel ini, nyatanya mampu dipadukan dengan kajian ekofeminsime dan pembelaan tokoh wanita. Tokoh ratih dituduh macam-macam perial kecantikan dan status jandanya. Itulah yang membuat Ratih disingkirkan oleh masyarakat. Stereotip negatif diberikan padanya.

Ratih adalah seorang janda yang memilki kecantikan luar biasa. Dia selalu memetik buah gayam di daerah pohon gayam. Semua bu-ibu dan para gadis iri terhadap kecantikannya. Terebih, sekarang Ratih telah menjadi janda. Lelaki mana yang tidak menjulur lidahnya dan melirik kedua bola matanya ketika bertemu dengan Ratih?

Dari sinilah permasalahan mulai muncul. Para gadis yang iri akan kecantikan Ratih serta para ibu-ibu yang cemburu pada Ratih, diamdiam mengikuti Ratih dan megintip Ratih dari didinding kamarnya yang berlubang. Semua percaya bahwa Ratih menjadi semulus dan secantik itu sebab dia sering mengoleskan buah gayam pada kulit langsatnya.

Perbuatan inipun dilakukan oleh para gadis dan wanita desa itu. Namun siapa sangka siapa duga, justru petakalah yang menghampiri mereka. Kulit mereka melepuh, dan gatal-gatal karena tak kuat terkena getah gayam. Merekapun dengan seenaknya menyalahkan Ratih dan menuduh ratih menjad biang keladi semuaa ini.

"Itu dia! Janda iblis!"

"Kau pengikut setan di sungai ini!"

"Gayam terkutukmu itu merusak tubuh kami!"

"Gunduli saja rambutnya! Rambut itu penuh dengan sihir!"

"Kita habisi saja janda ini sebelum memakan korban lagi!"

Umpatan-umpatan dalam penggalan cerpen itu menunjukkan bentuk korelasi antara wanita dan alam. Perlakuan terhadap wanta dan alam seolah sama. Wanita memberi kesuburan dan alam juga memberi kehidupan. 
Itu sisi positifnya, sedangkan sisi negatifnya adalah alam biasanya dieksploitasi dan wanita juga demikian. Pengeksploitasian wanita dan alam sungguh nampak jelas dalam cerpen ini.

Cerpen tersebut seolah menunjukkan bahwa reaalita yang mendasari proses pengeksploitasian tersebut adalah alam numinus. Istilah alam numinus dikemukakan oleh Franz Magnis Suseno. Menurut Magniz Suseno (1984:85), alam numinus merupakan alam adikodrati. Numen juga diterjemahkan sebagai sebuah alam dewa, alam yang memiliki kekuatan di atas kekuatan manusia, atau alam gaib. Secara spesifik alam gaib merupakan alam yang keberadaanya serta eksistensinya sulit diteroka oleh panca indera.

Dasar dari gaib atau mistsis inilah yang mampu merubah sikap manusia untuk memberikan stereotip negatif pada orang yang ditemui atau pada alamnya. Sifat-sifat gaib negatif yang berupa keirian, kecemburuan seolah menjadi representasi dalam diri manusia yang kemudian diwujudkan melalui bentuk eksploitasi terhadap keduanya.

\section{KESIMPULAN}

Cerpen yang memiliki muatan mistisisme adalah (1) Pemilin Kematian, (2) Biaju Direngkuh Rengas sungai Kahayan, (3) Malam Merah Ibu, dan (4) Janda Sungai Gayam. Keempat cerpen ini memiliki muatan mitsisisme ketika dibedah dan dimaknai seperti dalam bagian pembahasan. Penelitian lebih lanjut terkait dengan penelitian ini adalah temuan mistisisme dalam genre sastra yang lain guna memperkaya kazanah sastra Indonesia.
Callinicos, A. 2008. Menolak Postmodernisme. Yogyakarta: Resist Book.

Candradewi, R. 2014. Modernisme dan Postmodernisme Review Tulisan David Harvey. Jurnal Issue (1): 1-3.

Cremers, Agus dan Santo. 1997. Dukun, Mitos, dan Sihir. Yogyakarta: Kanisius.

Creswell, J.W. 1994. Research Design: Qualitative and Quantitative Approaches. California: Sage Publications, Inc.

Freud, Sigmund. 2002. Totem dan Tabu. Yogyakarta: Jendela.

Greetz, Clifford. 1989. Abangan, Santri, dan Priyayi dalam Masyarakat Jawa. Jakarta: Pustaka Jaya.

Keesing, George. 1981. Antropologi Budaya Jilid 2. Jakarta: Erlangga.

Khan, Hazrat Inayat. 2002. Kehidupan Spiritual. Yogyakarta: Pustaka Sufi.

Magnis Suseno, Franz. 1984. Etika Jawa: Sebuah Analisa Falsafi tentang Kebijaksanaan Hidup Jawa. Jakarta: Gramedia.

Peterson, Bob. 2004. Ilmu Ngrogo Sukma. Yogyakarta: Kreasi Wacana.

Rhamdhany, D.R. 2015. Pemilin Kematian. Malang: Universitas Negeri Malang.

Sugiyono. 2013. Metodologi Penelitian Pendidikan. Bandung: Penerbit Alfabeta. Widjanto, Tjahjono. 2018. Jagad Alus Mistis Jawa dalam Cerpen-Cerpen Danarto dan Fantasi Magis Ternate dalam Novel Cala Ibi Karya Nukila Amal. Jurnal Kajian Sastra Jentera Vol 7.

Zarabizadeh, Saeed. 2011. Mendefinisikan Mistisisme. Jurnal Kanz Philoshophia Vol 1.

\section{DAFTAR PUSTAKA}

